\section{Factors associated with alcohol intake and alcohol abuse among women in Belo Horizonte, Minas Gerais State, Brazil}

\author{
Fatores associados ao uso e abuso de álcool entre \\ mulheres em Belo Horizonte, Minas Gerais, Brasil
}

\author{
Factores asociados al consumo y abuso de \\ alcohol entre mujeres en Belo Horizonte, \\ Minas Gerais, Brasil
}

Ísis Eloah Machado 1

Francisco Carlos Félix Lana 1

Mariana Santos Felisbino-Mendes 1

Deborah Carvalho Malta 1,2

\footnotetext{
${ }_{1}$ Escola de Enfermagem, Universidade Federal de Minas Gerais, Belo Horizonte, Brasil.

2 Ministério da Saúde, Brasília, Brasil.

Correspondence I. E. Machado Escola de Enfermagem, Universidade Federal de Minas Gerais.

Rua Conde Ribeiro do Vale 836, apto. 102, Belo

Horizonte, $M G$

31030-470, Brasil.

isiseloah@gmail.com
}

\section{Abstract}

The main objective of this cross-sectional study was to analyze factors associated with alcohol consumption among adult women living in Belo Horizonte, Minas Gerais State, Brazil, in 2011. Data for Belo Horizonte were obtained from the VIGITEL system (Telephone-Based Surveillance of Risk and Protective Factors for Chronic Diseases). Alcohol use was defined as self-reported intake of at least one dose in the previous 30 days; alcohol abuse was defined as four or more doses on at least one occasion during the same period. Polytomous logistic regression was used to evaluate factors associated with alcohol use and abuse. Alcohol use was more prevalent among women 25 to 34 years of age. Alcohol abuse was associated with age, schooling, health status, and smoking. The results suggest the need for policies to prevent alcohol abuse among women, especially targeting those who are younger, single, smokers, and with more education.

Alcoholic Beverages; Alcoholism; Alcohol Drinking; Women

\section{Resumo}

O objetivo do presente estudo foi analisar os fatores associados ao consumo de álcool entre mulheres adultas no Município de Belo Horizonte, Minas Gerais, Brasil, baseado em dados do Sistema de Vigilância de Fatores de Risco e Proteção para Doenças Crônicas por Inquérito Telefônico no ano de 2011. Considerou-se uso habitual a referência de ingestão de pelo menos uma dose de bebida alcoólica nos últimos 30 dias, e abuso a ingestão de quatro ou mais doses em pelo menos uma ocasião. A regressão logística polinomial foi utilizada para avaliar os possíveis fatores associados ao uso e abuso de álcool. O uso habitual de álcool foi mais prevalente entre as mulheres na faixa etária de 24 a 34 anos ( $p<0,05)$, enquanto o abuso esteve associado à age mais jovem, alta escolaridade, classificação do estado de saúde como ruim e tabagismo $(p<0,05)$. Os resultados apontam a necessidade de políticas intersetoriais de prevenção do consumo abusivo de álcool entre as mulheres, principalmente as jovens, fumantes, escolarizadas e que não vivem em união estável.

Bebidas Alcoólicas; Alcoolismo; Consumo de Bebidas Alcoólicas; Mulheres 


\section{Introduction}

Alcohol is one of the few psychoactive drugs of which society both allows and encourages consumption; it is also the world's most widely consumed drug 1. In recent decades, alcohol consumption has grown worldwide, with most of the increase in developing countries 2. In Brazil, the world's fourth leading producer of distilled liquor and beer, drinking has expanded rapidly, a trend that can be associated with various factors such as advertising, low prices, and widespread availability 3,4 .

Low cost and easy access by all segments of society facilitate the spread of alcohol consumption, generating major concern in the academic and therapeutic communities and among families, in some countries raising concerns at the government level as well, since the high social cost of alcohol abuse is associated with crime, accidents, violence, unemployment, and other social problems 5 .

The concept of alcohol abuse has been used to describe two distinct phenomena. First, the "classical" concept linked to the clinical definition of alcohol addiction as an illness, is used to describe a consumption pattern that occurs over a prolonged period 6 . Second, it is used to describe a single episode of alcohol intake that leads to intoxication, generally defined as the consumption of five or more doses of alcoholic beverages for men or four or more doses for women, regardless of the pattern's frequency ${ }^{6}$. This latter definition, also known as "binge drinking" or heavy episodic alcohol consumption, was based on growing scientific evidence that these amounts increase the individual's risk of alcohol-related problems 7; this is the definition of alcohol abuse used in the current study.

Heavy episodic alcohol consumption accounted for more than half of the 75,000 deaths and some two-thirds of the 2.3 million potential years of life lost due to alcohol abuse in the United States in 2001 8. This behavior is associated with a variety of serious health and social problems, including sexually transmitted diseases, low workplace productivity, domestic violence, admissions to emergency healthcare services, acute myocardial infarction, and traffic accidents 9. The World Health Organization (WHO) estimates that in 2004, alcohol use, including excessive consumption, accounted for $4.5 \%$ of the global burden of disease, only slightly less than the separate burdens of smoking and hypertension ${ }^{3}$. It is also estimated that alcohol use causes 2.5 million deaths per year, with a considerable proportion in young people, ranking third among the main risk factors for premature death and disability ${ }^{3}$.
Alcohol consumption also involves a gender issue. Men and women differ in the amount and way they drink, besides in the social and health consequences to which they are exposed 10 . Due to biological factors, the same amount of alcohol consumed by women and men of the same weight produces a higher blood alcohol level in women. In addition, women are more prone to suffer not only the direct repercussions of their own drinking, but also the consequences of behavior induced by their partners' alcohol consumption, including domestic violence, traffic accidents, sexual abuse, and economic impact 11 .

According to recent research, binge drinking has become popular among adolescents and young adults, and in the last 10 years, consumption has increased among women, thus drawing extensive media attention ${ }^{6}$.

Qualitative studies have shown that consumption of alcohol, tobacco, and other psychoactive drugs in the turn of the millennium requires more in-depth gender approaches. These substances have been used due to their pleasure-enhancing effects, to improve social performance, to deal with difficult situations, and even to contain the anxiety resulting from gender contradictions experienced by women, such as social pressure, double workload, and countless chores and responsibilities 12 .

An analysis of reports by the VIGITEL system (Telephone-Based Surveillance of Risk and Protective Factors for Chronic Diseases) from 2006 to 2010 identified an increase in abusive consumption of alcoholic beverages by adult women in Brazil's State capitals and Federal District 13 . However, the year 2011 showed a slight drop in this indicator $(9.1 \%)$, so that it was no longer possible to statistically demonstrate this upward trend 14 . According to data from the same survey, Belo Horizonte, the capital of Minas Gerais State, ranks 7 th in heavy episodic alcohol consumption by adult women, reaching a prevalence of $11.6 \%$ (95\%CI: 8.9-14.2) in 2011, higher than the national average 14 .

Thus, despiteknowledge on the recent upward trend in alcohol use and abuse among women, information is still lacking on consumption patterns and their relations to socio-demographic and health characteristics in the city of Belo Horizonte. Such information is essential for formulating public health policies. The current study thus aimed to analyze the relationship between habitual alcohol use and alcohol abuse and socio-demographic and health factors among adult women in the city of Belo Horizonte. 


\section{Material and methods}

This was a cross-sectional study based on the sample of women in the city of Belo Horizonte who answered the VIGITEL survey in 2011.

In order to estimate the frequency of any risk factor in the adult population with a $95 \%$ confidence interval $(95 \% \mathrm{CI})$ and maximum error of two percentage points, VIGITEL interviews at least 2,000 persons per year in each of the Brazilian State capitals and the Federal District. This sample is obtained randomly from the adult population living in households served by at least one landline telephone in the study year. Sampling is done in two stages: systematic selection of 5,000 phone lines, followed by reselection to form 200-line replicates and selection of an individual 18 years or older from each household, to be interviewed 14,15.

As for the VIGITEL system's performance in the municipality of Belo Horizonte in 2011, of the calls made to 2,870 eligible phone lines, 2,006 resulted in complete interviews, or a $69.9 \%$ response rate (interviews conducted/eligible selected phone lines). The refusal rate (interviews refused/ eligible selected phone lines) in the same year was $1.9 \%$ (Primary data. Department for the Surveillance of Diseases and Non-Communicable Health Problems and Health Promotion, Health Surveillance Secretariat, Ministry of Health, Brazil, 2012). In addition to refusals, nonresponses also included constantly busy phone lines, lines with fax signals or connected to answering machines, or cases in which it was not possible to locate the selected individual in the household 15 .

Two patterns of alcohol consumption were studied: 1) habitual use, or reported consumption of any amount of alcoholic beverages at least once in the 30 days prior to the interview, not including alcohol abuse and 2) alcohol abuse, or reported consumption of four or more doses of alcohol on a single occasion, also in the 30 days prior to the interview.

Socio-demographic and health variables were used to characterize the alcohol consumption patterns and as possible factors associated with abusive consumption of alcoholic beverages. The target socio-demographic variables were: age, skin color, schooling, marital status, and labor market participation. Age was categorized in six brackets (18-24, 25-34, 35-44, 45-54, $55-64$, and 65 years or older); skin color was classified as white or non-white; and schooling was divided into three brackets (0-8, 9-11, and 12 years or more). Conjugal status was assessed as married/ in a common law partnership and was categorized as yes or no (yes equal to married or in a common law union and no equal to single, divorced, and widow); labor market participation was categorized as yes or no.

Health variables were: physical inactivity, recommended consumption of fruit and vegetables, poor health status, smoking, and overweight/ obesity. Physical inactivity included the four domains evaluated by VIGITEL: free-time (leisuretime), work-related, commuting, and domestic chores, and was categorized as yes or no 14 . Healthy eating was defined as the consumption of five or more portions of fruit and vegetables per day, categorized as yes or no, as recommended by the Guia Alimentar para a População Brasileira: Promovendo a Alimentação Saudável [Nutritional Handbook for the Brazilian Population: Promoting Healthy Eating] 16. Poor health status was also classified as yes or no, where individuals self-rated their health status as poor or very poor are assigned to the former category and those that rated their health as fair, good, or very good were in the latter. Smoking was classified as yes for current smokers and no for the rest. Excess weight was defined as body mass index (BMI) greater than or equal to $25 \mathrm{~kg} / \mathrm{m}^{2}$ for individuals 18 to 59 years of age and greater than or equal to $27 \mathrm{~kg} / \mathrm{m}^{2}$ for individuals 60 years or older 17 , and this variable was also categorized as yes or no.

Frequency estimates were calculated with $95 \%$ confidence intervals ( $95 \% \mathrm{CI})$. Bivariate analyses were conducted to assess the association between socio-demographic and health-related characteristics and use and abuse of alcoholic beverages, using the Pearson chi-square test and calculation of odds ratios (OR) with 95\%CI. Variables that were associated with alcohol use and abuse with statistical significance of $20 \%$ $(\mathrm{p}<0.20)$ were included in a multivariate model according to decreasing order of significance. A polytomous logistic regression analysis was used with an estimator of robust variance, using the Wald test and statistical significance set at 5\% (p $<0.05$ ) as criteria for inclusion of significant variables in the model and to guarantee statistical precision 18 .

Weighting factors used by VIGITEL were considered in order to reduce the impact generated by non-universal coverage of landline telephony. The final weight attributed to each individual is the result of the multiplication of three factors: the inverse of the number of phone lines in the household, the number of adults in the household, and the post-stratification weight, in order to approach the population data from the 2000 population census of the Brazilian Institute of Geography and Statistics (IBGE), considering the characteristics sex, age, and schooling 14,15. 
The analyses were performed in the survey module of Stata, version 9.1 (Stata Corp., College Station, USA).

The study was approved by the Institutional Review Board through submission in the Brazil Platform, case CAAE no. 02308712.1.0000.0022.

\section{Results}

In 2011, among the 2,006 individuals interviewed in the city of Belo Horizonte, 1,170 were women. The female population, the object of this study, showed a mean age of 40.3 years (95\%CI: 39.041.6); the most widely represented age bracket was 25 to 34 years $(23.5 \%)$ and the least was 55 to 64 years $(9.6 \%)$. The majority of the study population was non-white (63.3\%), and approximately half of the sample had a maximum of eight years of schooling. As for conjugal status, $45.6 \%$ were married or living in a stable union and $56.1 \%$ were in the labor force (Table 1).

As for health-related characteristics (Table 1), $13.2 \%$ of the women were sedentary and $71.8 \%$ failed to reach the recommended daily consumption of five portions of fruit and vegetables. Only $5.0 \%$ rated their health as poor; $11.7 \%$ smoked; and $39.8 \%$ were overweight or obese.

Prevalence rates for habitual alcohol consumption and alcohol abuse among adult women in the city of Belo Horizonte in 2011 were $31.3 \%$ and $11.6 \%$, respectively. The 25 to 34 year age bracket showed the highest moderate alcohol consumption, and the 18 to 24 year bracket showed the highest prevalence of alcohol abuse. Odds ratios for alcohol consumption were higher among the younger age brackets as compared to 65 years or older (Table 1).

As for education, the highest rates of habitual use and alcohol abuse were in women with 12 years of schooling or more $(15.1 \%$ and $19.2 \%$ respectively), and there was a decrease in the group with 0 to 8 years of schooling $(21.6 \%$ and $7.0 \%$, respectively). For habitual use, women with more schooling showed $\mathrm{OR}=1.2$ as compared to those with 0 to 8 years of schooling, and the association was stronger for alcohol abuse, i.e., women with more education showed an OR of 3.3 compared to those with 8 years of school or less (Table 1).

Married women or those in stable unions showed lower alcohol consumption, regardless of the pattern, with an OR of 0.6 for habitual use and 0.5 for abuse. The same was found for those that rated their health status as poor, with odds ratios of 0.3 and 0.1 , respectively, for habitual use and alcohol abuse. Women smokers consumed more alcohol, with an OR of 1.4 for habitual use and 3.5 for alcohol abuse. There was no associa- tion between skin color, labor market participation, physical inactivity, consumption of fruit and vegetables, or excess weight and alcohol use or abuse (Table 1).

For alcohol abuse, multivariate analysis showed that younger women presented higher odds ratios, reaching 5.20 in the 18 to 24 year bracket. The same was found for more schooling $(\mathrm{OR}=3.20)$ and smoking $(\mathrm{OR}=4.75)$. Poor self-rated health status showed an inverse association $(\mathrm{OR}=0.10)$, while conjugal status showed no statistical association with alcohol abuse. As for habitual use, only the 25 to 34 year bracket showed a statistically significant association $(\mathrm{OR}=1.21)($ Table 2$)$

\section{Discussion}

Smoking, younger age range and highest level of schooling were positively associated with alcohol abuse among women in Belo Horizonte. Poor self-rated health status, unlike the other target factors, showed a negative association, suggesting that it could be a protective factor against alcohol abuse. Only the 25 to 34 year bracket was associated with habitual alcohol consumption.

Risk factors for chronic non-communicable diseases include harmful use of alcohol, ranking third among risk factors for premature death and disabilities. Alcohol-related diseases include cardiovascular, liver, cancer, neurological disorders, depression, and increased exposure to accidents and violence ${ }^{3}$. According to the $\mathrm{WHO}$, abundant evidence shows that alcohol also contributes to an increase in disease burden related to communicable diseases 3 .

Due to women's physiological characteristics, they are exposed to further serious consequences of alcohol abuse, such as: increased osteoporosis 19 , breast cancer 20 , reproductive problems 21 , heart disease and stroke 22 , and brain damage 23 . They also show a more rapid progression to dependency as compared to men 24; propensity to develop liver cirrhosis in less time and with lower amounts of alcohol 25; alcohol use during pregnancy can also lead to toxicity to the embryo and fetal teratogenicity 26 . Episodes of acute intoxication also expose women to greater risk of violence, such as sexual assault 24 .

In addition to biological factors, socio-cultural issues also play an important role in determining gender differences in alcohol consumption 27. Cultural issues, social contact, frequent participation in parties, and mass events expose males to greater consumption of alcoholic beverages. In addition, more frequent and heavier drinking has historically been linked to the 
Table 1

Alcohol consumption rates and crude odds ratios among adult women in Belo Horizonte, Minas Gerais State, Brazil, according to socio-demographic and health characteristics. Telephone Surveillance System for Risk and Protective Factors for Chronic Diseases (VIGITEL), 2011.

\begin{tabular}{|c|c|c|c|c|c|c|c|c|c|}
\hline \multirow{2}{*}{$\begin{array}{l}\text { Socio-demographic and } \\
\text { health characteristics }\end{array}$} & \multicolumn{2}{|c|}{ Total population } & \multirow{2}{*}{$\begin{array}{l}\text { Do not drink } \\
\text { alcohol } \\
\text { \% (SE) }\end{array}$} & \multicolumn{3}{|c|}{ Habitual alcohol use * } & \multicolumn{3}{|c|}{ Alcohol abuse ** } \\
\hline & $\mathrm{n}$ & $\%$ (SE) & & $\%$ (SE) & OR (95\%Cl) & $\mathrm{p}$-value $* * *$ & $\%$ (SE) & OR $(95 \% \mathrm{Cl})$ & p-value $* \star \star$ \\
\hline \multicolumn{10}{|l|}{ Age bracket (years) } \\
\hline$\geq 65$ & 259 & $10.2( \pm 0.8)$ & $87.9( \pm 2.4)$ & $8.8( \pm 2.1)$ & 1.0 & & $3.3( \pm 1.2)$ & & \\
\hline $55-64$ & 186 & $9.6( \pm 0.9)$ & $80.9( \pm 3.6)$ & $11.0( \pm 3.2)$ & $1.4(0.6-3.1)$ & 0.46 & $8.1( \pm 2.1)$ & $2.7(1.1-6.8)$ & 0.04 \\
\hline $45-54$ & 230 & $15.2( \pm 1.2)$ & $75.8( \pm 3.1)$ & $11.7( \pm 2.2)$ & $1.5(0.8-3.0)$ & 0.21 & $12.4( \pm 2.3)$ & $4.4(1.9-10.4)$ & $<0.01 * * *$ \\
\hline $35-44$ & 188 & $21.5( \pm 1.7)$ & $79.4( \pm 3.2)$ & $10.7( \pm 2.4)$ & $1.3(0.7-2.8)$ & 0.42 & $9.9( \pm 2.2)$ & $3.4(1.4-8.2)$ & $<0.01 * \star \star$ \\
\hline $25-34$ & 196 & $23.5( \pm 2.1)$ & $68.8( \pm 5.0)$ & $19.3( \pm 4.4)$ & $2.8(1.3-6.0)$ & $<0.01 * \star \star$ & $11.8( \pm 3.3)$ & $4.6(1.8-12.2)$ & $<0.01 * \star *$ \\
\hline $18-24$ & 111 & $20.0( \pm 2.2)$ & $68.0( \pm 6.0)$ & $13.5( \pm 4.8)$ & $2.0(0.7-5.3)$ & 0.17 & $18.4( \pm 4.6)$ & $7.3(2.8-19.0)$ & $<0.01 * \star \star$ \\
\hline \multicolumn{10}{|l|}{ Skin color } \\
\hline Non-white & 632 & $63.3( \pm 2.1)$ & $73.5( \pm 2.7)$ & $13.9( \pm 2.2)$ & 1.0 & & $12.6( \pm 1.9)$ & & \\
\hline White & 522 & $36.7( \pm 2.1)$ & $77.6( \pm 2.7)$ & $12.4( \pm 2.3)$ & $0.8(0.5-1.5)$ & 0.56 & $10.0( \pm 1.6)$ & $0.8(0.5-1.2)$ & 0.26 \\
\hline \multicolumn{10}{|l|}{ Schooling (years) } \\
\hline $0-8$ & 414 & $51.1( \pm 2.2)$ & $78.4( \pm 3.2)$ & $14.6( \pm 2.8)$ & 1.0 & & $7.0( \pm 2.0)$ & & \\
\hline $9-11$ & 424 & $31.2( \pm 1.8)$ & $75.1( \pm 2.7)$ & $10.1( \pm 1.8)$ & $0.7(0.4-1.3)$ & 0.28 & $14.8( \pm 2.3)$ & $2.2(1.1-4.5)$ & $0.03^{* \star *}$ \\
\hline$\geq 12$ & 332 & $17.7( \pm 1.2)$ & $65.7( \pm 3.2)$ & $15.1( \pm 2.3)$ & $1.2(0.7-2.2)$ & 0.47 & $19.2( \pm 2.8)$ & $3.3(1.6-6.7)$ & $<0.01^{\star \star \star *}$ \\
\hline \multicolumn{10}{|l|}{ Married/Stable union } \\
\hline No & 652 & $54.4( \pm 2.2)$ & $70.5( \pm 2.9)$ & $15.0( \pm 2.5)$ & 1.0 & & $14.5( \pm 2.1)$ & & \\
\hline Yes & 513 & $45.6( \pm 2.2)$ & $80.8( \pm 2.3)$ & $11.1( \pm 1.9)$ & $0.6(0.4-1.1)$ & 0.11 & $8.1( \pm 1.5)$ & $0.5(0.3-0.8)$ & $<0.01 \star \star \star *$ \\
\hline \multicolumn{10}{|l|}{ In the labor market } \\
\hline No & 558 & $43.9( \pm 2.2)$ & $79.4( \pm 3.1)$ & $11.7( \pm 2.6)$ & 1.0 & & $8.9( \pm 2.1)$ & & \\
\hline Yes & 612 & $56.1( \pm 2.2)$ & $71.8( \pm 2.5)$ & $14.5( \pm 2.0)$ & $1.4(0.8-2.5)$ & 0.29 & $13.7( \pm 1.8)$ & $1.7(0.9-3.1)$ & 0.08 \\
\hline \multicolumn{10}{|l|}{ Sedentary lifestyle } \\
\hline No & 1,003 & $86.8( \pm 1.7)$ & $74.5( \pm 2.1)$ & $14.1( \pm 1.8)$ & 1.0 & & $11.4( \pm 1.4)$ & & \\
\hline Yes & 167 & $13.2( \pm 1.7)$ & $79.5( \pm 4.8)$ & $7.9( \pm 2.2)$ & $0.5(0.3-1.0)$ & 0.06 & $12.6( \pm 4.3)$ & $1.0(0.5-2.3)$ & 0.93 \\
\hline \multicolumn{10}{|l|}{ Recommended } \\
\hline \multicolumn{10}{|l|}{ consumption of fruit } \\
\hline \multicolumn{10}{|l|}{ and vegetables } \\
\hline No & 776 & $71.8( \pm 1.8)$ & $73.5( \pm 2.5)$ & $14.3( \pm 2.1)$ & 1.0 & & $12.2( \pm 1.7)$ & & \\
\hline Yes & 394 & $28.2( \pm 1.8)$ & $79.3( \pm 2.7)$ & $10.8( \pm 2.2)$ & $0.7(0.4-1.2)$ & 0.21 & $10.0( \pm 1.8)$ & $0.8(0.5-1.3)$ & 0.28 \\
\hline \multicolumn{10}{|l|}{ Poor self-rated health } \\
\hline \multicolumn{10}{|l|}{ status } \\
\hline No & 1,118 & $95.0( \pm 1.1)$ & $74.2( \pm 2.0)$ & $13.7( \pm 1.7)$ & 1.0 & & $12.1( \pm 1.4)$ & & \\
\hline Yes & 52 & $5.0( \pm 1.1)$ & $93.2( \pm 3.8)$ & $5.0( \pm 3.6)$ & $0.3(0.1-1.3)$ & 0.11 & $1.7( \pm 1.1)$ & $0.1(0.0-0.4)$ & 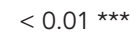 \\
\hline \multicolumn{10}{|l|}{ Smoking } \\
\hline No & 1,041 & $88.3( \pm 1.6)$ & $77.2( \pm 2.0)$ & $13.1( \pm 1.8)$ & 1.0 & & $9.6( \pm 1.3)$ & & \\
\hline Yes & 129 & $11.7( \pm 1.6)$ & $59.2( \pm 6.7)$ & $14.6( \pm 3.8)$ & $1.4( \pm 0.7-3.0)$ & 0.32 & $26.2( \pm 5.6)$ & $3.5(1.8-7.1)$ & $<0.01 * \star *$ \\
\hline \multicolumn{10}{|l|}{ Overweight/Obese } \\
\hline No & 619 & $60.2( \pm 2.4)$ & $75.6( \pm 2.5)$ & $11.1( \pm 1.9)$ & 1.0 & & $13.3( \pm 2.0)$ & & \\
\hline Yes & 393 & $39.8( \pm 2.4)$ & $75.9( \pm 3.4)$ & $13.0( \pm 2.9)$ & $1.2(0.6-2.2)$ & 0.63 & $11.1( \pm 2.2)$ & $0.8(0.5-1.4)$ & 0.50 \\
\hline Total & 1,170 & 100.0 & $75.0( \pm 1.9)$ & $13.3( \pm 1.6)$ & & & $11.6( \pm 1.4)$ & & \\
\hline
\end{tabular}

OR: odds ratio; SE: standard error; 95\% $\mathrm{Cl}$ : 95\% confidence interval.

* Consumption of any amount of alcohol in the 30 days prior to the interview;

** Consumption of four or more doses of alcohol in the 30 days prior to the interview;

$\star \star \star$ Statistical significance, $\mathrm{p}<0.05$. 
Polynomial logistic regression model for alcohol consumption pattern among adult women in Belo Horizonte, Minas Gerais State, Brazil. Telephone Surveillance System for Risk and Protective Factors for Chronic Diseases (VIGITEL), 2011.

\begin{tabular}{|c|c|c|c|c|c|c|}
\hline \multirow[t]{2}{*}{ Variables } & \multicolumn{3}{|c|}{ Habitual alcohol use * vs. non-use } & \multicolumn{3}{|c|}{ Alcohol abuse * vs. non-use } \\
\hline & OR & $95 \% \mathrm{Cl}$ & p-value & OR & $95 \% \mathrm{Cl}$ & p-value \\
\hline \multicolumn{7}{|c|}{ Age bracket (years) } \\
\hline$\geq 65$ & 1.00 & & & 1.00 & & \\
\hline $55-64$ & 1.36 & $0.59-3.10$ & 0.47 & 2.07 & $0.79-5.38$ & 0.14 \\
\hline $45-54$ & 1.51 & $0.76-3.03$ & 0.24 & 2.68 & $1.09-6.59$ & $0.03 * \star \star$ \\
\hline $35-44$ & 1.37 & $0.63-2.94$ & 0.43 & 2.27 & $0.91-5.67$ & 0.08 \\
\hline $25-34$ & 2.87 & $1.21-6.82$ & $0.02 * \star \star$ & 3.01 & $1.03-8.75$ & $0.04 * \star \star$ \\
\hline $18-24$ & 2.32 & $0.76-7.04$ & 0.14 & 5.20 & $1.72-15.69$ & $<0.01 * \star \star$ \\
\hline \multicolumn{7}{|c|}{ Schooling (years) } \\
\hline $0-8$ & 1.00 & & & 1.00 & & \\
\hline $9-11$ & 0.60 & $0.29-1.23$ & 0.16 & 1.86 & $0.80-4.31$ & 0.15 \\
\hline$\geq 12$ & 1.09 & $0.58-2.05$ & 0.80 & 3.20 & $1.47-6.97$ & $<0.01 * \star \star$ \\
\hline \multicolumn{7}{|c|}{ Poor self-rated health } \\
\hline \multicolumn{7}{|l|}{ status } \\
\hline No & 1.00 & & & 1.00 & & \\
\hline Yes & 0.27 & $0.05-1.45$ & 0.13 & 0.10 & $0.02-0.57$ & $0.01 * \star \star$ \\
\hline \multicolumn{7}{|l|}{ Smoking } \\
\hline No & 1.00 & & & 1.00 & & \\
\hline Yes & 1.52 & $0.67-3.46$ & 0.32 & 4.75 & $2.36-9.58$ & 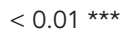 \\
\hline
\end{tabular}

OR: odds ratio; $95 \% \mathrm{Cl}$ : $95 \%$ confidence interval.

* Consumption of any amount of alcohol in the 30 days prior to the interview;

** Consumption of four or more doses of alcohol in the 30 days prior to the interview;

$\star \star \star$ Statistical significance, $\mathrm{p}<0.05$

characteristics of strength, toughness, aggressiveness, and power, i.e., male gender roles 28 Meanwhile, women that drink have been negatively stigmatized by society 28 .

With current changes in society, women are redefining their gender identities in relation to men, and the increase in alcohol consumption may reflect changes in social positions 29. A new pattern of women's activity was established after World War II, and beginning in the 1970s, women entered the labor market more intensively, occupying professions that were previously exclusive to the male population 30 and adopting practices such as smoking that had been considered part of the male world ${ }^{31}$. This overall trend has continued, bringing both benefits and negative consequences.

A recent study in Brazil on women and gender in public and private spaces points to important changes in perceptions by men and women on the social division of labor, body and sexuality, reproductive health and abortion, domestic violence, democracy, and politics. This study the expansion of women's labor market participation and references to greater independence and freedom of action and decision-making 32 .

Behaviors that were historically considered exclusive to men, such as going out to bars, are currently being observed among women, especially younger ones. Besides, women have not been as heavily stigmatized in recent decades for consuming alcoholic beverages. Second, women's massive entry into the labor market, increasing the opportunities for controlling their fertility and other indicators of gender role equality, may be important factors contributing to the decrease in differences between the genders in alcohol consumption 31,33 .

No association was found between alcohol consumption and labor market participation, but there was an association between schooling and increased alcohol abuse.

Corroborating the current study's results, Almeida Filho et al. 34, in a study in 2001 in Salvador, Bahia State, found that individuals of both sexes with high purchasing power showed more episodes of alcohol abuse. In this case, one can infer that in higher income strata, there is 
more disposable income to spend on liquor or that its use is associated with social status, ease of access, and fewer social constraints. Another explanation would be that in social strata with lower schooling and income, more people belong to religions that recommend avoiding alcoholic beverages 35,36 .

In a national survey in the United States, Keyes et al. 33 found evidence of a closing gender gap in alcohol consumption, especially in younger cohorts. In Brazil, a study among schoolchildren 13 to 15 years of age already shows that alcohol use is proportionally equal between girls and boys in terms of regular consumption, with a higher proportion of girls that have ever tried alcoholic beverages 37 . On the other hand, the $1^{\text {st }}$ National Survey on Alcohol Consumption Patterns in the Brazilian Population 38, conducted in 2005-2006, failed to detect differences between the genders for age at first use of alcohol.

Other studies within adults have also identified greater alcohol abuse in younger age brackets $3,39,40$, corroborating the current study. This characteristic may be explained by the birth cohort effect, since society has proven to be more permissive towards alcohol consumption 33, and by the social and cultural stimulus acting on the age group: participation in parties and events and advertising campaigns targeting this audience 41 .

Importantly, the mass media portrays alcohol as a factor for socialization, a mean to reach desired emotional states within a group and to overcome shyness, in addition to being depicted as commonplace, harmless, and attractive, leaving the impression that everyone drinks 42 . Getting drunk is viewed as natural and desirable in celebration, and drunken scenes are considered fun and inoffensive 42 . While advertisements for alcoholic beverages already routinely portrayed women as objects, that is, valuing their sculptural bodies as a reward for men that consumed alcohol, they now (although incipiently) depict active women that drink and have fun with the guys.

Changes in women's roles may also explain the identification of marriage/stable union as a protective factor against alcohol abuse, even though this variable did not remain significantly associated in the final model (while other studies have confirmed this association) 7,34,43. A study of data from the VIGITEL survey for the overall Brazilian population 40 and a study on the population of the city of São Paulo 44 found that marriage/stable union was a protective factor against alcohol abuse in both genders, even after adjusting for other variables 40 . These differences suggest that the relationship between alcohol consumption and conjugal status, plus the other so- cio-demographic characteristics, require further research in Brazil.

The study showed an association between tobacco and alcohol in women, corroborating findings by Silveira et al. 7 in a review study. Studies among Brazilian adolescents also pointed to this association $37,45,46$, showing that some risk practices act together. Despite these findings, it is important to highlight that heavy investment in policies for smoking prevention and promotion of cessation showed a downward trend in smoking rates from 1989 to 2003 47. However, in recent years, from 2006 to 2011, smoking has declined in Brazilian men and remained stable in women 14, indicating a behavior change among women.

A qualitative study on tobacco use and gender pointed to new symbolic and material meanings for women's smoking. By analogy, given the similarities between the habits, it may be possible to extrapolate such findings to alcohol consumption. The study showed that cigarettes played an important support role in dealing with difficulties in daily survival, reducing anxiety and loneliness, besides serving as a source of pleasure and relaxation 48 . Likewise, a qualitative study of women with chronic alcohol use revealed a past of suffering and episodes of violence. As for alcohol use and dependence, the study showed that women's drinking may offer the possibility of escaping from suffering in an attempt to remain happy and sociable, while often proving to be solitary, depressive, and self-destructive in practice 49 . The current study did not approach this chronic consumption pattern, but new (qualitative) research is necessary for a more in-depth analysis of heavy episodic alcohol consumption in women in order to better understand the phenomenon.

In the current study, women who did not rate their health status as poor showed a higher prevalence of alcohol abuse, even in the multivariate analysis. This finding contradicts observations in the literature showing a higher proportion of alcohol abuse among individuals with chronic illnesses 10,43. Other studies have shown health benefits from alcohol consumption, but such protection only holds true with light-to-moderate drinking 10,50.

Although self-rated health status is an important proxy for mortality rate, showing high reliability, it cannot be considered a strictly objective measure to assess health, since it reflects not only exposure to disease but also such constructs as well-being, satisfaction, control over one's own life, physical self-sufficiency, and quality of life 51 . The fact that consumption of alcoholic beverages is related to situations of leisure and feelings of well-being and pleasure may contribute to the 
observed association between better self-rated health status and alcohol abuse, since the concept of alcohol abuse used in the current study does not refer to problematic drinking.

Although no association was observed between healthy eating and sedentary lifestyle and alcohol use or abuse, according to Barry \& Piazza-Gardner 52, recent research points to the phenomenon known as "drunkorexia". This term refers to the behavior of persons that engage in alcohol abuse and display a major concern with their body weight, reducing their calorie intake from food and working out more and with heavier exercise. The phenomenon has been identified among university students, especially women 52 , once again calling atention to the importance of proposing measures to control alcohol consumption in young, highly educated women.

Some limitations of the study should be discussed, such as the possibility of underestimating the rates of alcohol abuse, which is still socially stigmatized, especially for women (the target of this study), even with guaranteed confidentiality and anonymity. This highlights the importance of studies to assess the validity of the questionnaire used by the VIGITEL system. Furthermore, due to the cross-sectional design of the surveys, the observed associations may not indicate causality, since the determinants and outcome were measured in a single moment.

Another important limitation is that the different definitions of alcohol abuse used in the studies tend to reduce their comparability. Even when an indicator refers to the amount of alcohol consumed on one occasion, there are also different concentrations of alcohol in the various beverages available on the market and in homemade drinks, in addition to the lack of standard definitions of "glasses", "shots", and beverage containers in general.

It is also essential to extend qualitative research on alcohol and gender through studies that can elucidate the general, individual, and unique determinants of the problem.

\section{Final remarks}

A decrease in harmful alcohol consumption should lead to a reduction in the alarming rates of accidents and violence, as well as in chronic diseases that have alcohol as a risk factor. This in turn should decrease expenditures by the health system and social costs. A better understanding of the problem is thus crucially important. The current study based on the VIGITEL system and other surveys in Brazil provide important tools for detecting levels and patterns of alcohol consumption, revealing possible trends in various social groups. Such studies also allow evaluating the applied strategies. Another key point is the population's support. All these elements are indispensable for planning, orienting, and implementing public policies on alcohol consumption.

Finally, although Brazil has taken a lead over some other countries with the enforcement of a tougher law on drinking-and-driving (the socalled Lei Seca, literally "Dry Law"), there is still a tendency to treat alcoholic beverages as simple merchandise, which leads to serious social and public health problems. Thus, much remains to be done to prevent harm and reduce the costs resulting from harmful alcohol use.

\section{Resumen}

El objetivo del presente estudio fue analizar los factores asociados al consumo de alcohol entre mujeres adultas en el municipio de Belo Horizonte, Minas Gerais, Brasil, basados en datos del Sistema de Vigilancia de Factores de Riesgo y Protección para Enfermedades Crónicas, recabados por encuesta telefónica en el año 2011. Se consideró uso habitual a la ingestión de por lo menos una dosis de bebida alcohólica en los últimos 30 días, y abuso a la ingestión de cuatro o más dosis en por lo menos una ocasión. La regresión logística polinomial se utilizó para evaluar los posibles factores asociados al consumo y abuso del alcohol. El consumo habitual de alcohol fue más prevalente entre las mujeres en la franja etaria de 24 a 34 años $(p<0,05)$, mientras que el abuso estuvo asociado a la edad más joven, alta escolaridad, clasificación del estado de salud como malo y tabaquismo ( $p<0,05)$. Los resultados apuntan la necesidad de políticas intersectoriales de prevención del consumo abusivo de alcohol entre las mujeres, principalmente entre aquellas jóvenes, fumadoras, escolarizadas y que no viven con pareja estable.

Bebidas Alcohólicas; Alcoholismo; Consumo de Bebidas Alcohólicas; Mujeres 


\section{Contributors}

I. E. Machado participated in the study design, data analysis, and writing of the article. F. C. F. Lana contributed to the interpretation of the findings and critical revision of the article's content. M. S. Felisbino-Mendes collaborated in the data analysis and critical revision of the article's content. D. C. Malta collaborated in the interpretation of the findings and critical revision of the article's content.

\section{Acknowledgments}

The authors wish to thank the Health Surveillance Secretariat of the Brazilian Ministry of Health for granting access to the data.

\section{References}

1. Instituto Nacional de Câncer. Inquérito domiciliar sobre comportamentos de risco e morbidade referida de doenças e agravos não transmissíveis: Brasil, 15 capitais e Distrito Federal, 2002-2003. Rio de Janeiro: Instituto Nacional de Câncer; 2004.

2. World Health Organization. The World Health Report 2002: reducing risks, promoting healthy life. http://www.who.int/whr/2002/download/en/ (accessed on 09/Jun/2011).

3. World Health Organization. Global status report on alcohol and health. Geneva: World Health Organization; 2010.

4. Caetano R, Laranjeira RA. A 'perfect storm' in developing countries: economic growth and the alcohol industry. Addiction 2006; 101:149-52.

5. Moraes E, Campos GM, Figlie NB, Laranjeira RR, Ferraz MB. Conceitos introdutórios de economia da saúde e o impacto social do abuso de álcool. Rev Bras Psiquiatr 2006; 28:321-5.

6. Berridge V, Herring R, Thom B. Binge drinking: a confused concept and its contemporary history. Soc Hist Med 2009; 22:597-607.

7. Silveira CM, Silveira CC, Silva JG, Silveira LM, Andrade AGA, Andrade LHG. Epidemiologia do beber pesado e beber pesado episódico no Brasil: uma revisão sistemática da literatura. Rev Psiquiatr Clín 2008; 35 Suppl 1:31-8.
8. Brewer RD, Swahn MH. Binge drinking and violence. JAMA 2005; 294:616-8.

9. Foster RK, Marriott HE. Alcohol consumption in the new millennium - weighing up the risks and benefits for our health. Nutr Bull 2006; 31:286-331.

10. Rehm J, Room R, Monteiro M, Gmel G, Graham K, Rehn N, et al. Alcohol use. In: Ezzati M, Lopez A, Rodgers A, Murray C, editors. Comparative quantification of health risks. Global and regional burden of disease attributable to selected major risk factors. v. 1. Geneva: World Health Organization; 2004. p. 959-1101.

11. Room R, Jernigan D, Carlini-Marlatt B, Gureje O, Mäkelä K, Marshall M, et al. Alcohol in developing societies: a public health approach. Helsinki: Finnish Foundation for Alcohol Studies; 2002.

12. Trotta-Borges MT, Simões-Barbosa RH. As marcas de gênero no fumar feminino: uma aproximação sociológica do tabagismo em mulheres. Ciênc Saúde Coletiva 2009; 14:1129-39.

13. Secretaria de Vigilância em Saúde; Secretaria de Gestão Estratégica e Participativa, Ministério da Saúde. VIGITEL Brasil 2010: vigilância de fatores de risco e proteção para doenças crônicas por inquérito telefônico. Brasília: Ministério da Saúde; 2011. 
14. Secretaria de Vigilância em Saúde; Secretaria de Gestão Estratégica e Participativa, Ministério da Saúde. VIGITEL Brasil 2011: vigilância de fatores de risco e proteção para doenças crônicas por inquérito telefônico. Brasília: Ministério da Saúde; 2012.

15. Moura EC, Morais Neto OL, Malta DC, Moura L, Silva NN, Bernal R, et al. Vigilância de fatores de risco para doenças crônicas por inquérito telefônico nas capitais dos 26 estados brasileiros e no Distrito Federal (2006). Rev Bras Epidemiol 2008; 11 Suppl 1:20-37.

16. Coordenação Geral da Política de Alimentação e Nutrição, Secretaria de Atenção à Saúde, Ministério da Saúde. Guia alimentar para a população brasileira: promovendo a alimentação saudável. Brasília: Ministério da Saúde; 2006.

17. World Health Organization. Physical status: the use and interpretation of anthropometry. Geneva: World Health Organization; 1995.

18. Selvin S. Statistical analysis of epidemiologic data 3rd Ed. New York: Oxford University Press; 2004.

19. Kanis JA, Johansson H, Johnell O, Oden A, De Laet C, Eisman JA, et al. Alcohol intake as a risk factor for fracture. Osteoporosis Int 2005; 16:737-42.

20. Singletary KW, Gapstur SM. Alcohol and breast cancer: review of epidemiologic and experimenta evidence and potential mechanisms. JAMA 2001; 286:2143-51

21. Emanuele MA, Wezeman F, Emanuele NV. Alcohol's effects on female reproductive function. Alcohol Res Health 2002; 26:274-81.

22. Ikehara S, Iso H, Toyoshima H, Date C, Yamamoto A, Kikuchi S, et al. Alcohol consumption and mortality from stroke and coronary heart disease among Japanese men and women. The Japan Collaborative Cohort Study. Stroke 2008; 39:2936-42.

23. Hommer DW. Male and female sensitivity to alcohol-induced brain damage. Alcohol Res Health 2002; 27:181-5.

24. Chermack ST, Booth BM, Curran GM. Gender differences in correlates of recent physical assault among untreated rural and urban at-risk drinkers: role of depression. Violence Vict 2006; 21:67-80.

25. Becker U, Deis A, Sørensen TIA, Grønbæk M, Borch-Johnsen K, Muller CF, et al. Prediction of risk of liver disease by alcohol intake, sex, and age: a prospective population study. Hepatology 1996; 23:1025-9.

26. Martinez-Frias ML, Bermejo E, Rodriguez-Pinilla E, Frias JL. Risk for congenital anomalies associated with different sporadic and daily doses of alcohol consumption during pregnancy: a casecontrol study. Birth Defects Res Clin Mol Terato 2004; 70(4 Pt A):194-200.

27. Kerr-Corrêa F, Tucci AM, Hegedus AM, Trinca LA, Oliveira JB, Floripes TMF, et al. Drinking patterns between men and women in two distinct Brazilian communities. Rev Bras Psiquiatr 2008; 30:235-42.

28. Nolen-Hoeksema S. Gender differences in risk factors and consequences for alcohol use and problems. Clin Psychol Rev 2004; 24:981-1010.

29. Lyons AC, Willott SA. Alcohol consumption, gender identities and women's changing social positions. Sex Roles 2008; 59:694-712.
30. Hoffmann R, Leone ET. Participação da mulher no mercado de trabalho e desigualdade da renda domiciliar per capita no Brasil: 1981-2002. Nova Economia 2004; 4:35-58.

31. Wolle CC, Sanches M, Zilberman ML, Caetano R, Zaleski M, Laranjeira RR, et al. Differences in drinking patterns between men and women in Brazil. Rev Bras Psiquiatr 2011; 33:367-73.

32. Fundação Perseu Abramo. Mulheres brasileiras e gênero nos espaços público e privado. http:// www.fpabramo.org.br/o-que-fazemos/pesquisasde-opiniao-publica/pesquisas-realizadas/pes quisa-mulheres-brasileiras-nos-es (accessed 18/ Nov/2012).

33. Keyes KM, Grant BF, Hasin DS. Evidence for a closing gender gap in alcohol use, abuse, and depen dence in the United States population. Drug Alcohol Depend 2008; 93:21-9.

34. Almeida Filho N, Lessa I, Magalhães L, Araújo MJ, Aquino E, Kawachi I, et al. Alcohol drinking patterns by gender, ethnicity, and social class in Bahia, Brazil. Rev Saúde Pública 2004; 38:45-54.

35. Barros MBA, Botega NJ, Dalgalarrondo P, MarínLeón L, Oliveira HB. Prevalence of alcohol abuse and associated factors in a population-based study. Rev Saúde Pública 2007; 41:502-9.

36. Instituto Brasileiro de Geografia e Estatística. Censo demográfico 2010: características gerais da população, religião e pessoas com deficiência http://www.sidra.ibge.gov.br/bda/tabela/listabl. asp? $\mathrm{z}=\mathrm{t} \& \mathrm{O}=1 \& \mathrm{i}=\mathrm{P} \& \mathrm{e}=\mathrm{l} \& \mathrm{c}=3457$ (accessed on $12 /$ $\mathrm{Jul} / 2012)$.

37. Malta DC, Mascarenhas MDM, Porto DL, Duarte EA, Sardinha LM, Barreto SM, et al. Prevalência do consumo de álcool e drogas entre adolescentes: análise dos dados da Pesquisa Nacional de Saúde Escolar. Rev Bras Epidemiol 2011; 14 Suppl 1: 136-46.

38. Laranjeira R, Pinsky I, Zaleski M, Caetano R. I levantamento nacional sobre os padrões de consumo de álcool na população brasileira. Brasília: Secretaria Nacional Antidrogas; 2007.

39. Galduróz JCF, Caetano R. Epidemiologia do uso de álcool no Brasil. Rev Bras Psiquiatr 2004; 26:3-6.

40. Moura EC, Malta DC. Consumo de bebidas alcoólicas na população adulta brasileira: característi cas sociodemográficas e tendência. Rev Bras Epidemiol 2011; 14 Suppl 1:61-70.

41. Richardson A, Budd T. Alcohol, crime and disorder: a study of young adults. Report. London: Home Office, Research, Development and Statistics Directorate; 2003

42. Pinsky I, editor. Publicidade de bebidas alcoólicas e os jovens. São Paulo: Fundação de Amparo à Pesquisado Estado de São Paulo; 2009.

43. Costa JS, Silveira MF, Gazalle FK, Oliveira SS, Hallal PC, Menezes AM, et al. Heavy alcohol consumption and associated factors: a population-based study. Rev Saúde Pública 2004; 38:284-91.

44. Silveira CM, Wang YP, Andrade AG, Andrade LH Heavy episodic drinking in the Sao Paulo epide miologic catchment area study in Brazil: gender and sociodemographic correlates. J Stud Alcohol Drugs 2007; 68:18. 
45. Barreto SM, Giatti L, Casado L, Moura L, Malta DC. Exposição ao tabagismo entre escolares no Brasil. Ciênc Saúde Coletiva 2010; 15(2 Suppl):3027-34.

46. Strauch ES, Pinheiro RT, Silva RA, Horta BL. Uso de álcool por adolescentes: estudo de base populacional. Rev Saúde Pública 2009; 43:647-55.

47. Monteiro CA, Cavalcante TM, Moura EC, Claro RM, Szwarcwald CL. Population-based evidence of a strong decline in the prevalence of smokers in Brazil (1989-2003). Bull World Health Organ 2007; 85:501-68.

48. Trotta-Borges MT, Simões-Barbosa RH. Cigarro "companheiro": o tabagismo feminino em uma abordagem crítica de gênero. Cad Saúde Pública 2008; 24:2834-42.
49. Cesar BAL. O beber feminino: a marca social do gênero feminino no alcoolismo em mulheres [Master's Thesis]. Rio de Janeiro: Fundação Oswaldo Cruz; 2005.

50. Karlamangla AS, Sarkisian CA, Kado DM, Dedes H, Liao DH, Kim S, et al. Light to moderate alcohol consumption and disability: variable benefits by health status. Am J Epidemiol 2009; 169:96-104.

51. Hofelmann DA, Blank N. Auto-avaliação de saúde entre trabalhadores de uma indústria no sul do Brasil. Rev Saúde Pública 2007; 41:777-87.

52. Barry AE, Piazza-Gardner AK. Drunkorexia: understanding the co-occurrence of alcohol consumption and eating/exercise weight management behaviors. J Am Col Health 2012; 60:236-43.

Submitted on 14/Aug/2012

Final version resubmitted on 29/Dec/2012

Approved on 17/Jan/2013 